УАK $352 / 353$

ББК 66.3(0),124

DOI 10.22394/1682-2358-2017-6-124-130

E.V. Rygina, post-graduate student of the Public Administration and Political Science Department, Volgograd Institute of Management, Branch of the Russian Presidential Academy of National Economy and Public Administration

\section{PUBLIC OPINION \\ LEADERS \\ IN THE POLITICAL \\ PROCESSES \\ OF LOCAL SELF-GOVERNMENT}

The influence of public opinion leaders in the formation of local selfgovernment bodies, the adoption and implementation of political decisions and other political processes of local self-government is considered. Characteristics of public opinion leaders are described and complemented, and the specificity of their impact at the local level is proved. The typology of leaders of public opinion is determined.

Key words and word-combinations: leaders of public opinion, public opinion, political process, local self-government.
E.B. Рвгина, аспирант кафедрь государственного управления и политологии Волгоградского института управления - филиала Российской академии народного хозяйства и государственной службы при Президенте РФ (email: zudovaev@mail.ru)

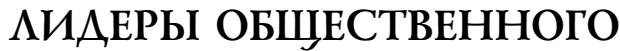 МНЕНИЯ В ПОАИТИЧЕСКИХ ПРОЦЕССАХ МЕСТНОГО САМОУПРАВАЕНИЯ}

\begin{abstract}
Аннотация. Рассматривается влияние лидеров общественного мнения на формирование органов местного самоуправления, принятие и исполнение политических решений и иных политических процессов местного самоуправления. Даются характеристики лидеров общественного мнения и доказывается специфика их воздействия на местном уровне. Определяется типология лидеров общественного мнения.

Ключевые слова и словосочетания: лидеры общественного мнения, общественное мнение, политический процесс, местное самоуправление.
\end{abstract}

B нием глобализации информационного общества возрастает роль общественного мнения. Выражкение массового настроения зачастую происходит через выступления говорящих от их мица общественных мидеров в виде пубмичных комментариев Аля среАств массовой информации (интервью Аля газет, участие в программах на ТВ и т.А.). Таким образом актуализируется рассмотрение влияния мидеров на мысли и суждения населения с 
учетом особенностей развития политических процессов в местном самоуправмении. Аидеры воздействуют на общественное мнение посредством формирования определенной позиџии, соответствуюшей их политическим убеждениям ици пропагандируемым ценностям.

Об ощутимом вмиянии мидеров общественного мнения на принимаемые гражданами решения впервые заявил известный американский соџиолог П.Ф. АазарсфельА, который в 1944 г. совместно с Б. Берельсоном и Г. Годэ разработал теорию двухступенчатого потока информации. На первой ступени потока мидеры общественного мнения получают информацию из среАств массовой информаџии, которую впослеАствии транслируют на широкую аудиторию в рамках второй ступени. П. Аазарсфельд опредемял следующие особенности у этой категории населения: коммуникабельность, способность расположить к себе людей, умение выступать в роли советчика и стремление к повышению знаний, что вполне уместно в современных реалиях [1].

Более Аостоверную причинно-следственную связь подтвержАают топ-менеАжеры исследовательской компании RoperASWЭА Кемлер и Ажон Берри, опредемяя портрет лидера мнения следующим образом: неравнодушный к чужим проблемам человек, использующий различные источники информаџии, который определяет ценность и значимость полученных данных и испытывает страсть к распространению идей посредством устных коммуникаџий [2]. Помимо указанных П. Аазарсфельдом сильных мидерских качеств, последние делают акцент не только на стремлении быть в центре внимания, но и на желании приносить пользу окружающим цюдям.

В научном пространстве активно обсуждаются соџиально-психологические особенности мидеров мнений [3], эффективность их деятельности в российском Интернете [4], а также комплексный анализ информационной ситуации в современном обществе [5]. Характеристика мидеров общественного мнения и выработка стратегии поведения становится попукярной темой в преАпринимательской среде и медиапространстве. В сложившихся условиях понятие «маркетинг влияния» - один из самых попумярных инструментов в продвижении брендов по всему миру [6], в первую очередь благодаря фактору доверия мидерам общественного мнения [7]. Аидеры мнений используются как технология продвижения бизнеса, например в качестве рекламы товара или услуги [8]. В таком случае в этой роли может выступать совершенно обычный человек, знаменитость или эксперт в определенной области, но непременно яркая харизматическая кичность, которая напрямую обшается с Аоверяюшей ей аудиторией. Следовательно, соџиальный статус мидера общественного мнения важен, но может принимать абсолютно мюбые формы в зависимости от специфики населения, на которое он оказывает влияние.

Существует и противоположная точка зрения: по мнению немеџкого фицософа и психолога К. Ясперса, манипуляџии массами невозможны в силу ее полного безразличия и нежелания принимать участие в чем-либо, связанном с социально-политической жизнью. Он утверждает, что власть «не хочет расставаться с имюљией своей силь», так как не в состоянии признать, что «безразличие масс относится к их сущности, это их единственная практика» [9, с. 193]. Аостаточ- 
но сложно согласиться с мнением К. Ясперса о том, что масса не подаается изучению и исследованию, обходится без истины и без мотива, преАставляя собой неизвестное мюбого политического уравнения. На наш взгляА, манипулирование массовым сознанием возможно при выборе правильного механизма внушения, чаще всего с целью воздействия в пространстве принятия решения.

О разцичных технологиях управления общественным сознанием рассужАает Г.Г. Почепцов, рассматривая настроение и суждения населения как «универсальный переводчик» на примере стран Содружества Независимых Государств. С помощью телевидения «финансовые деньги» переходят в «информационные», а впоследствии в «политические» Аля обеспечения нового витка «финансовых» [10, с. 5-6], что указывает на прямую возможность зарабатывать деньги с помощью мидеров общественного мнения. По мнению Б. ГодАарда, подобные информационно-политические технологии встречаются и в Соединенных Штатах Америки, например модель «петля общественного мнения», в рамках которой средства массовой информации вцияют на $\Lambda и-$ Аеров общественного мнения, а те, в свою очередь, оказывают давление на круг «миџ, принимающих политические решения» [11, с. 216]. Эти теории позволяют Аать оџенку мидерам общественного мнения не только как посреАникам в субъектно-объектных отношениях от вцасти к народу, но и признать возможность их участия в политической жкизни общества как полноправных акторов.

Представляется, что к перечисленным мичным качествам мидеров общественного мнения следует добавить суббектиЊность, так как они транслируют только ту информаџию, которая соответствует их убеждениям и взгляАам. Уважая собственное Аостоинство, мидеры мнений будут стремиться найти сторонников идей, которые искренне разделяют, ибо в противном случае они рискуют потерять уважение в глазах окружающих. Исходя из этого, второй важной характеристикой является авторитетность, которая может поАкрепляться, например, профессионализмом, безупречной репутацией, принаАлежкностью к пользующейся уважкением семье. Аидер общественного мнения Аолжен подАерживать статусные характеристики посредством сочетания формальных и неформальных систем мидерства, потому что заслуженное в обществе положение Аостигается годами.

Совершенно очевидно, что общественное мнение всегда концентрируется вокруг наиболее популярных идей, актуальных и проблемных вопросов, как совокупность суждений и оџенок. ВАасть, выступая в роли политического фактора, стремится взять на себя функщии выражения общественного мнения с помощью подконтрольных или мояльных к ней средств массовой информаџии, что часто проявцяется на внутригосударственном политическом пространстве и трактуется как информационная война на международной арене. Помимо этого, преАставители органов власти могут проводить соџиальные опросы, трактовка результатов которых остается за организаторами, а также ангажировать мидеров общественного мнения, благодаря которым будут распространяться материалы и оценки, способствующие оформлению 
общественных чувств, и формироваться публичное настроение [12, с. 73-74] . Е.А. Марков описывает варианты воздействия власти на массовое настроение, но, учитывая рост уровня абсентеизма и недоверия к средствам массовой информаџии среди населения, гораздо привлекательнее кажется получение подАержки мидеров мнений, к которым по-прежнему прислушиваются мюди.

ВАияние мидеров общественного мнения на уровне местного самоуправмения гораздо выше, чем на уровне региона и страны в связи с целым рядом специфических тенденций и характеристик местной политической жизни. Вопервых, в городских и сельских поселениях повседневная жизнь субъектов политики кругцосуточно явцяется пубцичной, поскольку в рабочее и свободное время должностные Аица всегда на виду у населения, что подтверждают исследования А.В. Асотовой и Г.Г.Филиппова. Электорат нередко знаком со своими избранниками кично, знает основные вехи биографии, семью и близкое окружение представителей власти $[13$, с. 12]. Результаты работы политических Аеятелей, как правило, проявмяются в многообразных деталях и событиях, вызывая открытую реакцию населения в максимально короткие сроки.

Во-вторых, сокращение дистанџии между мунищипальными служащими и народом приводит к реализации упрощенного механизма обратной связи, а относительно небольшая численность населения позволяет быстро передавать мюбую информацию «из уст в уста». Формирование доверительного отношения к мидерам общественного мнения способствует согласию мюдей с высказанными им позициями, тем самым расширяя политические возможности. В итоге оформляются опредеменные мнения граждан по тому или иному вопросу.

В-третьих, наблюдается наследственная передача социального статуса. Так, советские мидеры общественного мнения «передали» положение в обществе своим детям. В конџе XX в. популяризировалось понятие «муниџипальная революция», по итогам которой Аолжно было измениться местное политическое пространство вместе с соотношениями сил межАу размичными группами

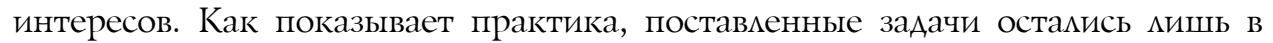
теории, так как спустя 25 мет после распада СССР отчетливо просматривается тенденция: бывшие руководители колхозов, партработники, успевшие активно поучаствовать в приватизаџии, возглавици якобы вновь созданную местную эмиту. Как итог, слеА былого влияния и Аоверия тянется Ао сих пор.

В-четвертых, влияние Интернета на уровне местного самоуправления значительно ниже, чем на региональном или федеральном, учитывая отсутствие повсеместного доступа к всемирной паутине и низкий уровень компьютерной грамотности населения. Четко сформулированная и психологически выверенная информаџия, передающаяся населению через мидеров общественного мнения, воспринимается абсолютной и незыблемой истиной, так как в Интернете местные процессы пользуются малой популярностью.

Пятой особенностью влияния мидеров общественного мнения на уровне местного самоуправления выступает дефиџит альтернативных источников, способных дать разъяснение по интересующему вопросу. В связи с отсутствием дискуссионных площадок, позвоцяющих публично обсужАать жизненно важные проблемы, создается информаџионный вакуум. В таких условиях ми- 
дер мнения выходит на первый план, так как осведомлен об актуальных событиях и имеет активную гражданскую позиџию. Подобная мысль проводится в работе А.А. Аавриковой, О.Е. Шумиловой и А.Ю. Исаевой, опредемяющих значительную роль и основной функционал мидеров общественного мнения в проџессе самоорганизации местных сообществ. На наш взгляА, основная роль принадмежит информаџионной, консультативной и коммуникационной функџиям, а мобилизационная и организационная функщии в силу российского менталитета отходят на второй план [14, с. 40-42].

Типологию мидеров общественного мнения, влияющих на политические проџессы в местном самоуправлении, можно преАставить в следующем виде:

- представители «околоһластных» структур, напрямую не ассоџиирующиеся с органами власти, но по факту полностью зависящие от последних (например, Аиректор школы, главный врач больниџы, преАставители общественных советов и объединений, начальник местного отделения полиџии и т.А.);

- представители бизнеса, предоставляющие рабочие места или выступающие посредниками экономического развития муниципалитета (собственник предприятия, владемец магазина и т.А.);

- представители культурьи, работа которых напрямую связана с публичностью и затрагивает все категории населения (редактор местной газеты, директор музыкальной школы, руководительдома культуры, библиотеки и т.А.);

- представители органов Власти как мидеры общественного мнения встречаются реже перечисленных типов с учетом современной тенденции недоверия населения к власти, но возможен механизм совмещения одного из первых типов с представительными функциями (редактор местной газеты избирается депутатом) или перехода из одной категории в Аругую (избрание собственника крупного преАприятия главой посемения).

Примером уникального вцияния мидеров общественного мнения на муниципальном уровне можно назвать проведение выборов. Средства массовой информации и иные рекламные акции не имеют должного эффекта в силу их критического проџента относительно массы населения (в каждом районе, как правило, действует всего одна газета, распространение рекламы не является главной задачей). Многие политтехнологи уже открыли феномен возможностей мидера общественного мнения на местном уровне. Изучая влияние общественного мнения на политические технологии избирательных кампаний, Е.А. Кленина и А.Е. Песков подчеркивают, что основные усилия в преАвыборной борьбе сосредотачиваются на цемевых группах избирателей, которые с большей долей вероятности пойдут голосовать, и изучении ценностных ориентаций и круга основных волнующих их вопросов [15, с. 103]. С учетом этого эффективность мидеров общественного мнения как «мокомотива» и манипумятора возрастает, так как он в курсе особенностей менталитета, неотъемлемой частью которого он и явцяется.

По мнению А.С. Ваторопина и М.С. Семиной, глава региона может опираться на существующих мидеров общественных мнений и таким образом опосредованно влиять на формирование общественного мнения в своем регионе [16, с. 77]. Эта идея позволяет провести аналогию с выборами на 
муниципальном уровне, где кандидат может собрать команду иидеров общественного мнения из преАставителей каждого городского или сельского поселения. Ведь именно к ним обращаются с высокой частотой за советом, с повседневными просьбами (бытовые вопросы, жизненные советы и т.А.), в том числе Аля обмена информацией, что позвоцяет навязывать собственную точку зрения относительно кандидатов на предстоящих выборах. Основные преимущества такого инструмента избирательной кампании в том, что килер общественного мнения не обязан досконально знать биографию и программу кандидата / партии, выступать на публичных предвыборных мероприятиях (мучше даже избегать подобного), Аостаточно выражать свое положительное мнение относительно субъекта моббирования.

В современном мире, учитывая значимость информаџионного пространства, невозможно действовать без осведомиенности об общественном мнении. В результате именно местное сообщество становится самостоятельным социальным фактором внедрения размичных государственных и региональных программ, так как «от преобладанияна местах носителей инновационных или традиционалистских ориентаций зависит реализация модернизационного проекта в России» [14, с. 40-42]. Высказанная А.А. Аавриковой, О.Е. Шумимовой и А.Ю. Исаевой мысль позволяет сделать вывод о значимости мидеров общественного мнения в утверждении государственной политики на местном уровне, так как именно они способны открытым и честным путем повциять на массовое настроение.

Сегодня наблюдается формирование общественного мнения, в основе которого межит не реализованный на политическом анализе выбор каждого отдельного гражАанина, а специально созданный и грамотно внедряемый информационный поток. Население воспринимает и мегитимизирует абсолютно мюбые результаты выборов, не акцентируя внимание на низком пороге явки и отсутствии графы

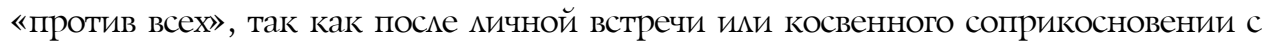
мидером общественного мнения будут уже готовы к объявленным итогам.

К сожалению, такая ситуация тормозит рост политической культуры среАи населения, мишенного альтернативного выбора ввиду использования размичных механизмов пропаганды, и развитие гражданского общества. Сущность местного самоуправления закцючается в том, чтобы управцять самим, без постороннего вмешательства. Власть Аолжна учитывать мнение населения, не злоупотребляя управлением информационным пространством через метоА порождения собственных потоков информащии, «удерживающих внимание массового сознания на нужных объектах» [10, с. 69]. Именно использование механизмов, мешающих непосредственному выражению воли народа, опреАемяет органы местного самоуправления как третий уровень органов государственной власти. В итоге непосредственная демократия становится понятием условным, не соответствующим заявценным принџипам.

\section{Библиографическийсписок}

1. Дергунова Н.В., Завгородняя М.Ю. Теории Пола Лазарсфельда вне «власти времени» // Власть. 2014. № 8. С. 123-126. 
2. Они не цепляют. В партизанском маркетинге от звезд никакого толку // Институт проблем предпринимательства. Частное образовательное учреждение профессионального дополнительного образования // SmartMoney: еженедельник. 2008. № 4 (94), 11 февр. URL: https:// www.ippnou.ru/article.php?idarticle $=003961$

3. Душкина М.P. Лидеры мнений: социально-психологические аспекты работы в области связей с общественностью // Аналитический портал «Гуманитарные технологии». 2011. 10 марта. URL: http://gtmarket.ru/laboratory/expertize/4263

4. Лазуткина Е.В. Лидеры мнений в информационном пространстве блогосферы Рунета // Вестник НГУ. Сер.: История, филология. 2016. № 6. С. 51-59.

5. Зубанова Л.Б. Действительность в суждениях медийных лидеров мнений // Социологические исследования. 2009. № 10. С. 109-119.

6. Судник А. Тришин А. Битва за лидеров мнений: как блогеры стали выгоднее любой рекламы // Forbes: финансово-экономический журнал. Карьера и свой бизнес: маркетинг. 2017. 14 июня. URL: http://www.forbes.ru/karera-i-svoy-biznes/345727-bitva-za-liderov-mneniy-kakblogery-stali-vygodnee-lyuboy-reklamy

7. Сердюкова B. Как правильно искать лидера мнений для вашего бизнеса / Информационный портал о маркетинге и коммуникациях в цифровой среде «Cossa». 2017. 28 марта. URL: http://www.cossa.ru/trends/156631/

8. Демчук T. Лидеры мнений: практическое руководство для бизнеса по сотрудничеству с блогерами // Нетология: университет интернет - профессий. Социальные медиа. 2017. 18 окт. URL: https://netology.ru/blog/lidery-mneniy

9. Ясперс К., Бодрийар Ж. Призрак толпы. М., 2007.

10. Почепцов Г. Г. Информационно-политические технологии. М., 2003.

11. Годдард Б. Кампания поддержки политических решений: справочник по политическому консультированию / под ред. Д.Д. Перлматтера. М., 2002.

12. Марков E.A. Роль общественного мнения в информационном взаимодействии власти и общества // Экономические и социальные перемены в регионе: факты, тенденции, прогноз. 2007. Вып. 40, (нояб. - дек.). С. 72-79.

13. Асотова А.В., Филиппов Г.Г. Политические элиты малых и средних городов России: перепутье или застой // Власть. 2009. № 6. С. 12-15.

14. Лаврикова А.А., Шумилова О.Е., Исаева А.Ю. Стратегии поведения в конфликтных ситуациях: особенности отражения в дискурсе российских лидеров общественного мнения // Известия ТулГУ. Гуманитарные науки. 2016. № 1. С. 40-49.

15. Кленина E.A., Песков А.Е. Влияние общественного мнения на политические технологии избирательных компаний // Вестник АГТУ. 2011. №2 (52). С. 102-108.

16. Ваторопин А.С., Семина М.С. Имидж главы субъекта РФ как лидера общественного мнения // Вестник ЮУрГУ. Сер.: Социально-гуманитарные науки. 2015. Т. 15, № 2. С. 77-79. 